\title{
Digital Learning System (DLS) Sebagai Model Pengembangan Media Pembelajaran Mata Kuliah Sistem Digital Berbasis Website Di Jurusan Teknik Informatika Universitas Hasyim Asy'ari Tebuireng Jombang
}

\author{
Terdy Kistofer ${ }^{1}$, Ginanjar Setyo Permadi ${ }^{2}$, Tanhella Zein Vitadiar ${ }^{3}$
}

Sistem Informasi, Fakultas Teknologi Informasi, Universitas Hasyim Asy’ari Tebuireng Jombang, Jl. Irian Jaya No 55 Tebuireng Jombang

\begin{tabular}{|c|c|}
\hline Info Artikel & ABSTRAK \\
\hline Riwayat Artikel & $\begin{array}{l}\text { Pada penelitian ini media pembelajaran yang dikembangkan } \\
\text { yaitu pembelajaran sistem digital. Pembelajaran sistem digital di }\end{array}$ \\
\hline Diterima: 02-11-2020 & Universitas Hasyim Asy'ari Tebuireng Jombang masih \\
\hline Direvisi: $18-11-2020$ & menggunakan sistem konvensional dengan sistem pengajaran \\
\hline Disetujui: $22-12-2020$ & yang mengandalkan lisan. Sehingga proses belajar mengajar \\
\hline Kata Kunci & pembelajaran sistem digital yang menerapkan Digital Learning \\
\hline$\overline{\text { Digital System; }}$ & System $(D L S)$ dengan dibuat beberapa bahan ajar terdiri dari \\
\hline Learning Media; & modul learning, video tutorial, latihan soal, simulasi percobaan, \\
\hline KKNI; & dan konsultasi secara online sehingga memudahkan peserta didik \\
\hline Digital Learning System & dalam belajar. Bukan hanya itu, pengajar juga dapat lebih siap \\
\hline (DLS); & $\begin{array}{l}\text { dalam pengajaran dan dapat membuat proses belajar mengajar } \\
\text { lebih efektif dan menarik. Hasil dari penelitian ini berdasarkan } \\
\text { respon mahasiswa mendapatkan hasil rata- rata } 3,06 \text { dengan }\end{array}$ \\
\hline$\triangle$ Corresponding Author & rating $81,2 \%$ (kategori baik). Dengan memanfaatkan Digital \\
\hline Terdy Kistofer, & Learning System (DLS) diharapkan dapat meningkatkan \\
\hline Tel. +62 85336551990 & semangat dan motivasi belajar bagi mahasiswa khususnya di \\
\hline terdykistofer@unhasy.ac.id & Universitas Hasyim Asy'ari Tebuireng Jombang dalam \\
\hline & $\begin{array}{l}\text { meningkatkan pengetahuan dan pembelajaran sistem digital } \\
\text { secara mandiri serta dapat mengaplikasikan sistem digital di } \\
\text { kehidupan sehari - hari. }\end{array}$ \\
\hline
\end{tabular}

\section{PENDAHULUAN}

Menurut [1] pendidikan adalah upaya menarik sesuatu pada manusia sebagai upaya memberikan pengalaman belajar terprogram berupa pendidikan formal, nonformal, dan informal di sekolah maupun di luar sekolah. Pendidikan tersebut berlangsung seumur hidup dengan tujuan mengoptimalkan kemampuan individu sehingga di masa depan mereka dapat memainkan peran hidup dengan tepat. Proses pembelajaran dapat dilakukan dengan beberapa model pembelajaran diantaranya model pembelajaran konvensional dan modern. Pada pembelajaran konvensional ini menggunakan pertemuan langsung dalam proses belajar mengajar sehingga konsep ini menghadapi kendala yang berkaitan dengan keterbatasan dalam tempat, lokasi dan waktu dalam penyelenggaraan dengan semakin meningkatnya aktifitas pelajar dan pengajar [2]. Metode Pembelajaran yang sangat modern dan konvensional berorientasi dan harapan untuk siswa dan guru ciptakan pembelajaran yang efektif capai kualitas secara efektif dunia belajar dan pendidikan [3]. Akan tetapi model pembelajaran konvensional dinilai sudah tidak efektif untuk saat ini mengingat sudah semakin majunya perkembangan teknologi. Dengan perkembangan teknologi komputer, teknologi informasi dan komunikasi, model pembelajaran modern (online) telah berkembang [4]. Model pembelajaran 
modern ini menggunakan Digital Learning System $(D L S)$ untuk memudahkan peserta didik dalam proses belajar. Digital Learning System $(D L S)$ adalah sistem pembelajaran digital modern yang menggunakan teknologi, baik perangkat lunak maupun perangkat keras, yang digunakan dalam proses belajar mengajar yang menarik dan interaktif. Universitas Hasyim Asy'ari Tebuireng Jombang yang sekarang sudah mengacu pada standard Kerangka Kualifikasi Nasional Indonesia (KKNI). Sehingga materi pada Metode Digital Learning System (DLS) berupa teks, modul, job sheet yang dikemas dalam bentuk software, pembelajaran mobile, gambar, video maupun animasi juga disesuaikan dengan standard KKNI yang dapat diakses dimanapun dan kapanpun secara online.

Pada penelitian ini media pembelajaran yang dikembangkan yaitu pembelajaran sistem digital. Pembelajaran sistem digital di Universitas Hasyim Asy'ari Tebuireng Jombang masih menggunakan sistem konvensional dengan sistem pengajaran yang mengandalkan lisan. Sehingga proses belajar mengajar sistem digital kurang optimal karena kompetensi dasar tidak dapat diajarkan secara utuh.

Penelitian terdahulu yang dilakukan oleh [5] dengan judul "Penggunaan Digital Learning System (DLS) Sebagai Pembelajaran Berbasis Teknologi Di Smp Negeri 5 Surabaya" dengan menandakan jika penggunaan Digital Learning System (DLS) dapat digunakan dalam kegiatan belajar mengajar dengan baik oleh guru dan siswa. Tetapi dari penelitian ini belum dijelaskan media pembelajaran yang digunakan dalam Digital Learning System (DLS).

Maka dari itu dikembangkan media pembelajaran sistem digital yang menerapkan Digital Learning System (DLS) berbasis website dengan dibuat beberapa bahan ajar terdiri dari modul learning, video tutorial, job sheet, simulasi percobaan, dan konsultasi secara online sehingga memudahkan peserta didik dalam belajar. Tidak hanya itu, pengajar juga dapat lebih siap dalam mengajar dan membuat proses belajar mengajar menjadi lebih efektif dan menarik [6]. Dengan memanfaatkan Digital Learning System (DLS) diharapkan dapat meningkatkan semangat dan motivasi belajar bagi peserta didik khususnya di Teknik Informatika Fakultas Teknologi Informasi Universitas Hasyim Asy'ari Tebuireng Jombang dalam meningkatkan pengetahuan dan pembelajaran sistem digital secara mandiri serta dapat mengaplikasikan sistem digital di kehidupan sehari - hari.

\section{METODE}

Metode yang digunakan dalam proses pembuatan website pembelajaran sistem digital di jurusan teknik informatika UNHASY berdasarkan WDLC ( Web Development Life Cycle) dimana merupakan sebuah proses pengembangan suatu sistem yang digunakan oleh analisis sistem, untuk mengembangkan sebuah website dan gambaran yang disampaikan kepada pengguna. Terdapat beberapa tahapan yang harus dilalui dalam membangun sebuah website dengan metode Web Development Life Cycle [7] 


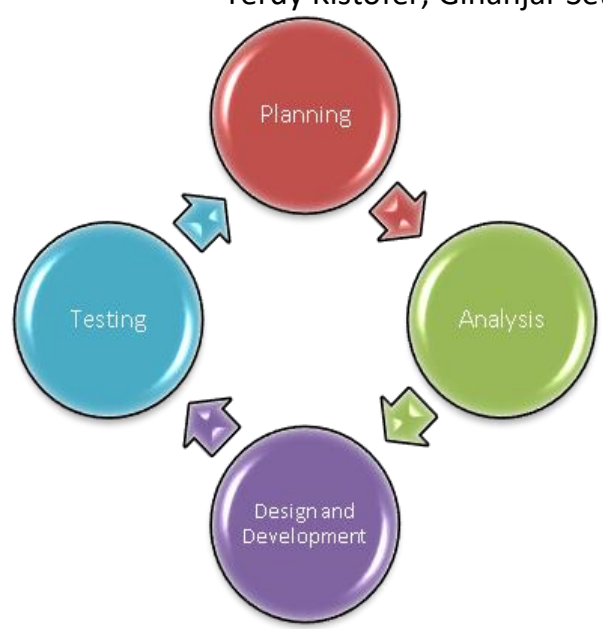

Gambar 1. Proses WDLC

\section{Website Planning}

Website planning atau perencanaan merupakan tahap pada penelitian dalam mencari informasi yang digunakan sebagai dasar pengembangan website. Pada penelitian ini dalam pengumpulan datanya dilakukan observasi dimana proses pembelajaran, analisis karakter peserta didik, dan RPS Berbasis KKNI serta analisis lingkungan belajar. Data observasi dilakukan pada awal penelitian. Data didapat dengan observassi lapangan dan studi pustaka.

\section{Website Analysis}

Tahap Analisis website merupakan tahapan dimana kita menganalisis apa yang dibutuhkan pengguna, mengumpulkan informasi dari pengguna, menganalisis fitur sistem dari aplikasi yang dibuat, data apa yang dibutuhkan dan hasil apa yang dibutuhkan.analisa website terdiri dari admin dan pengguna web dapat dilihat pada gambar 2

\begin{tabular}{|c|c|}
\hline Admin & Web \\
\hline II User Cek login & III Suport \\
\hline II Upload Data RPS & III Detail RPS \\
\hline II Upload Data Modul & III Detail Modul \\
\hline 11 Upload Data Jurnal & III Detail Jurnal \\
\hline & III Detail Jobsheet \\
\hline If Upload Data Jobsheet & III Detail Galery \\
\hline II Kelola data ( Simpan, Ubah,Hapus Edit) & Dinta User \\
\hline II Data User & III Content \\
\hline
\end{tabular}

Gambar 2. Analisis Kebutuhan Website Sistem Digital

\section{Website Design and Development}

Tabel relasi database website sistem digital pada gambar 3

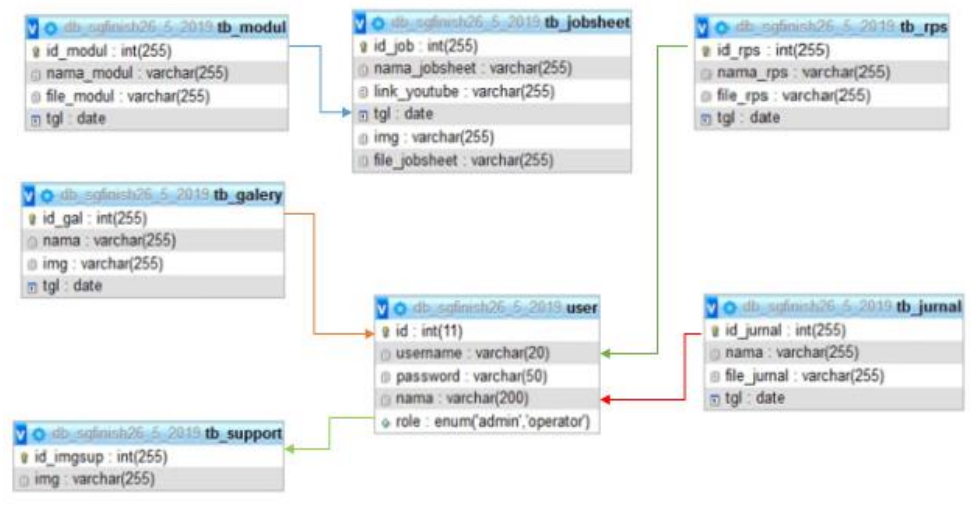

Gambar 3. Tabel Relasi Database 


\section{Website Testing}

Dalam tahap ini ditunjukkan penelitian pengembangan media pembelajaran website dengan penerapan Digital Learning System (DLS) pada mata kuliah sistem digital pada mahasiswa jurusan Teknik Informatika kelas A FTI dilakukan di UNHASY. Website yang dibuat mengunakan script HTML dan PHP native dapat dilihat pada gambar 4

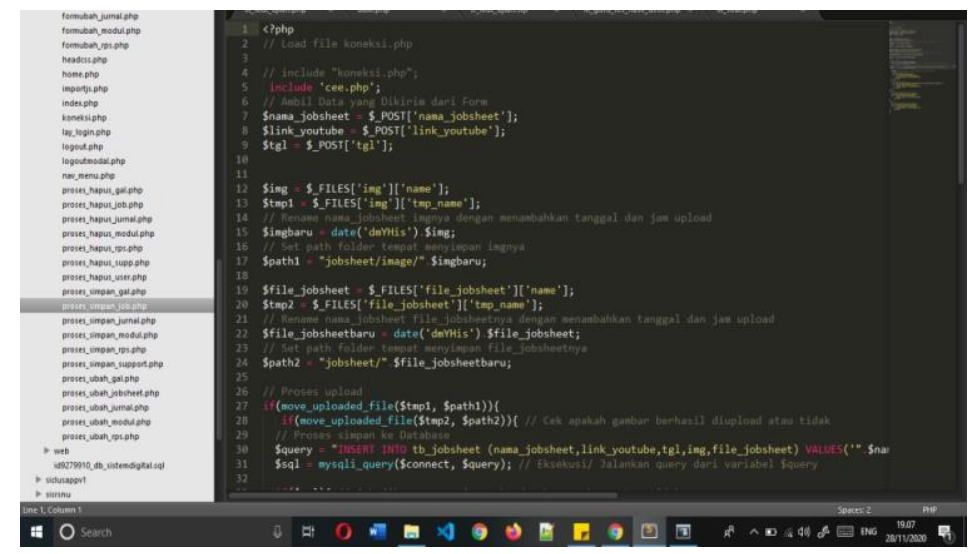

Gambar 4. Pemrograman Web Menggunakan PHP Native

Sedangkan untuk desain websitenya menggunakan framework bootstrap.Dimana tampilannya dapat dilihat pada gambar 5

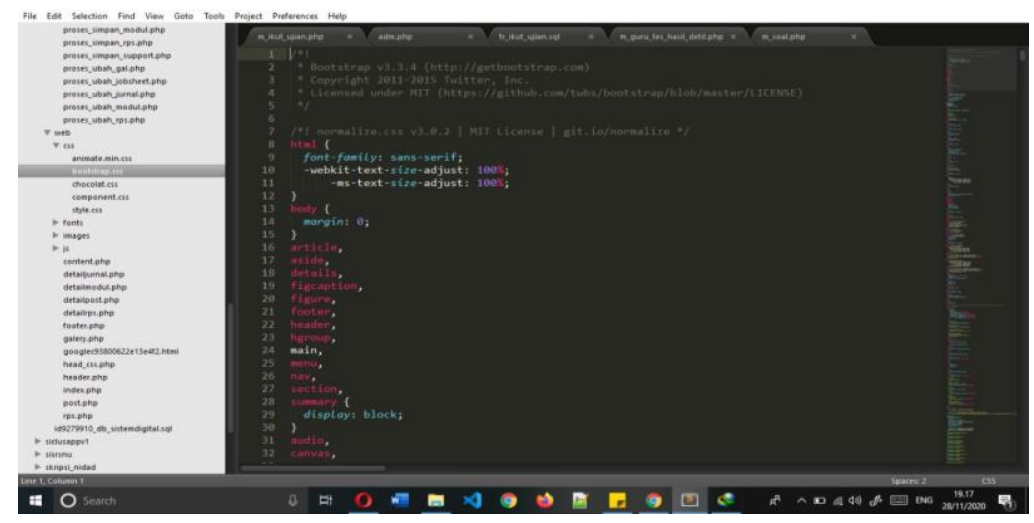

Gambar 5. Framework Bootstrap

Penyimpanan data website maka dibuatlah database yang menggunakan aplikasi XAMPP v3.2.4 seperti pada tampilan gambar 6

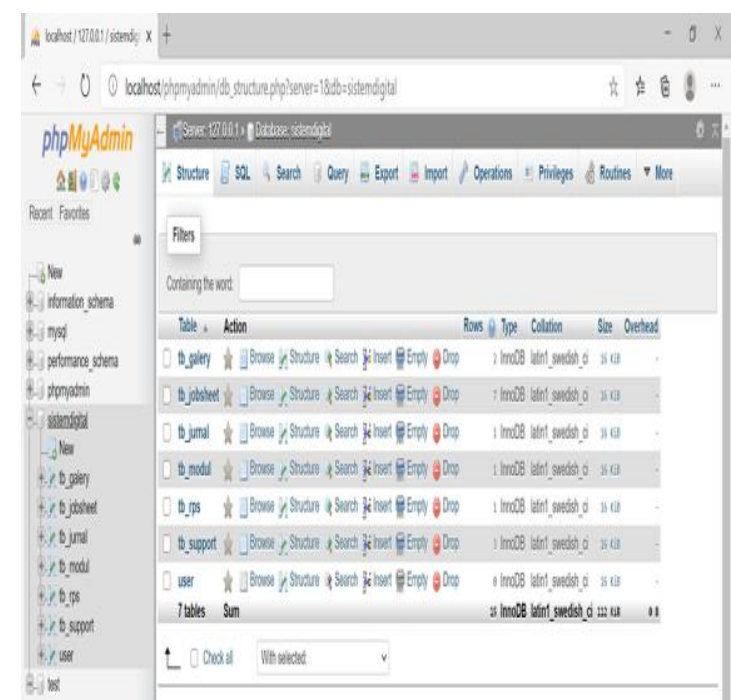

Gambar 6. Database Website Menggunakan XAMPP v3.2.4 
Digital Learning System (DLS) Sebagai Model Pengembangan Media Pembelajaran Mata Kuliah Sistem Digital Berbasis Website Di Jurusan Teknik Informatika Universitas Hasyim Asy'ari Tebuireng Jombang Terdy Kistofer, Ginanjar Setyo Permadi, Tanhella Zein Vitadiar

Database website yang sudah dibuat dimasukkan pada server menggunakan webhost seperti pada tampilan gambar 7

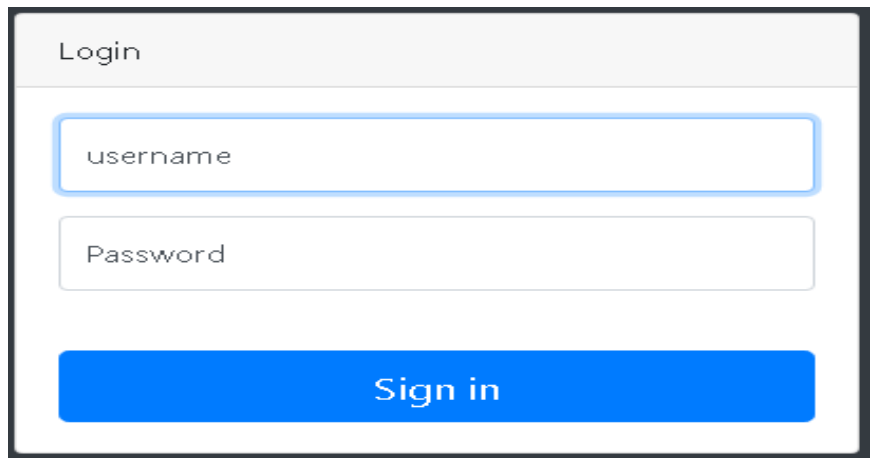

Gambar 7. Login Pada Server Admin

Data yang terdiri dari modul, jobsheet, jurnal, gambar, dan video learning diupload pada dasboard webhost yang sudah dibuat seperti pada Gambar 8

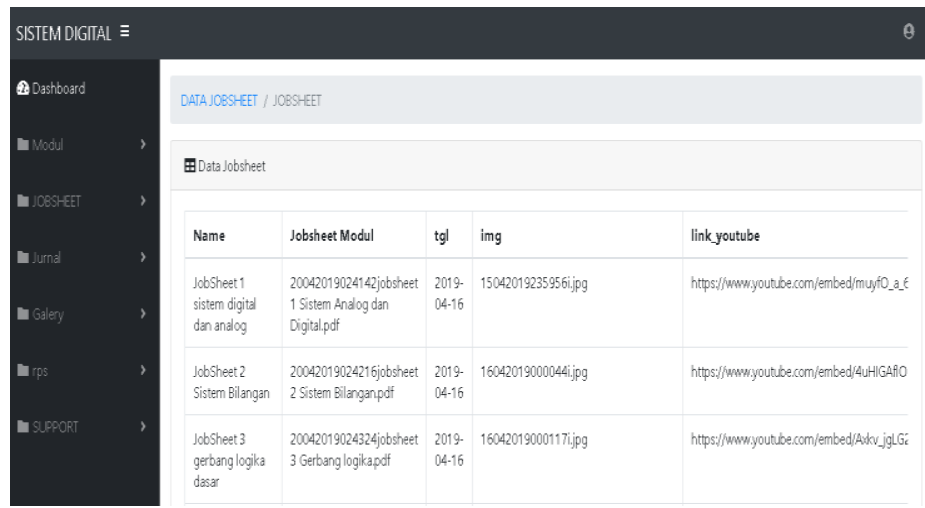

Gambar 8. Dasboard pada Webhost

\section{Pengolahan dan Analisa Data yang Digunakan}

Perhitungan data didapat dari angket respon mahasiswa pada saat uji coba skala kecil dengan jumlah 10 mahasiswa pada penelitian ini adalah menggunakan survey deskriptif menggunakan skala linkert didapat dari skor penilaian angket respon mahasiswa. Analisa hasil dilakukan dengan menghitung persentase jawaban dengan rumus sebagai berikut:

$$
\text { Rumus Indeks } \%=\frac{\text { Total Skor }}{\mathrm{Y}} \times 100
$$

Keterangan :

$\mathrm{X}=$ skor terendah pada jumlah responden likert $\mathrm{X}$

$\mathrm{Y}=$ skor tertinggi likert pada jumlah x $100=$ Konstanta.

Tabel 1 merupakan kriteria rating kategori pemilihan jawaban

\begin{tabular}{ll}
\multicolumn{2}{c}{ Tabel 1. Kriteria Rating Data Angket } \\
\hline Kriteria & Rating $(\%)$ \\
\hline Sangat Baik & $85-100$ \\
Baik & $70-84$ \\
Cukup Baik & $55-69$ \\
Kurang Baik & $50-54$ \\
Sangat kurang Baik & $0-49$ \\
\hline
\end{tabular}

\section{HASIL DAN PEMBAHASAN}

Pada penelitian ini yang dikembangkan penulis berupa sebuah media pembelajaran mata kuliah sistem digital dengan penerapan Digital Learning System (DLS) pada mahasiswa Prodi 
Informatika Fakultas Teknologi Informasi, UNHASY bertujuan untuk mengukur seberapa respon mahasiswa ketika belajar sistem digital sehingga dapat tuntas dan maksimal.

Hasil dari penelitian ini adalah sebagai berikut :

1. Website media pembelajaran sistem digital yang dikembangkan penulis untuk pembelajaran mengacu pada standar kompetensi KKNI untuk media belajar pada mahasiswa Teknik informatika FTI UNHASY yang mudah diakses menyenangkan dan efektif serta komunikatif, bukan hanya diwaktu perkuliahan tetapi juga di tempat lain serta dapat menerapkan sistem digital di kehidupan sehari - hari sebagaimana contoh pengaplikasian diantaranya jam digital, kamera digital, dan hanphone. Tampilan website yang sudah dibuat dapat dilihat pada gambar 9

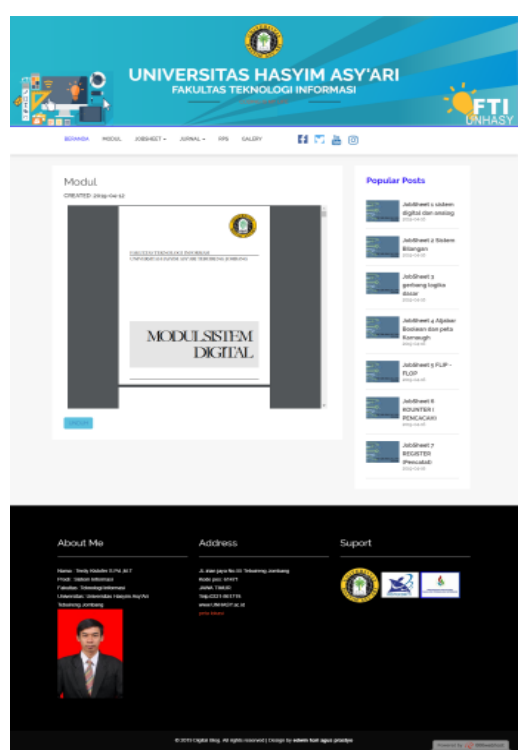

(a)

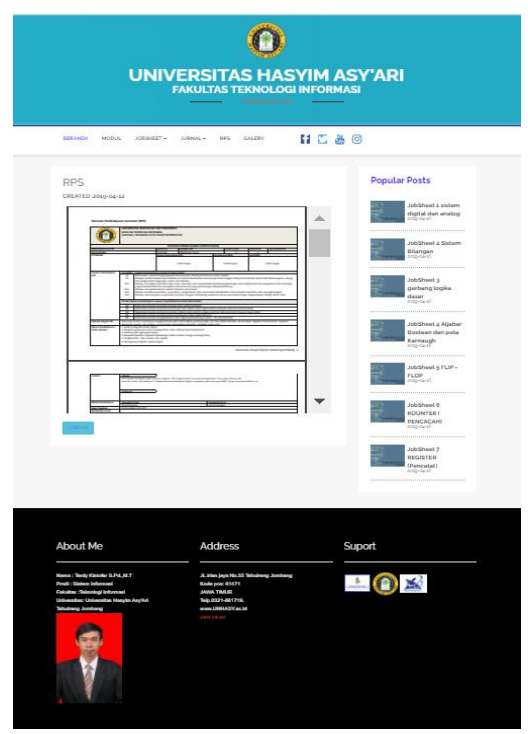

(c)

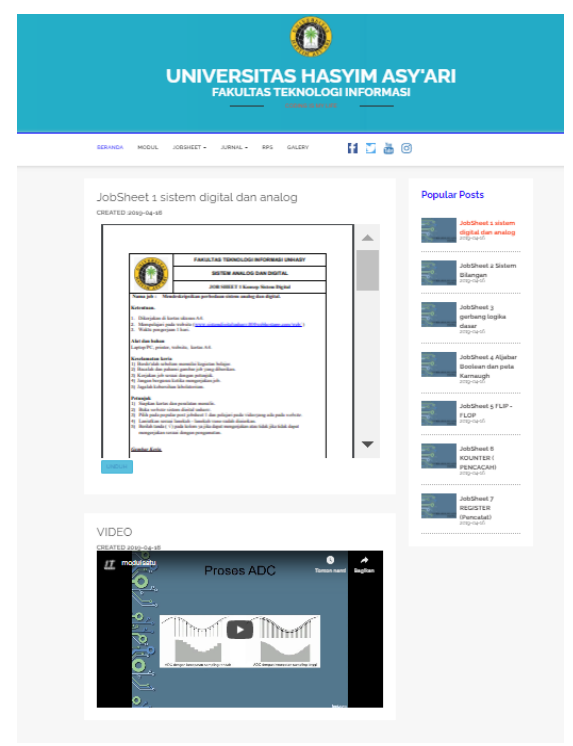

(b)

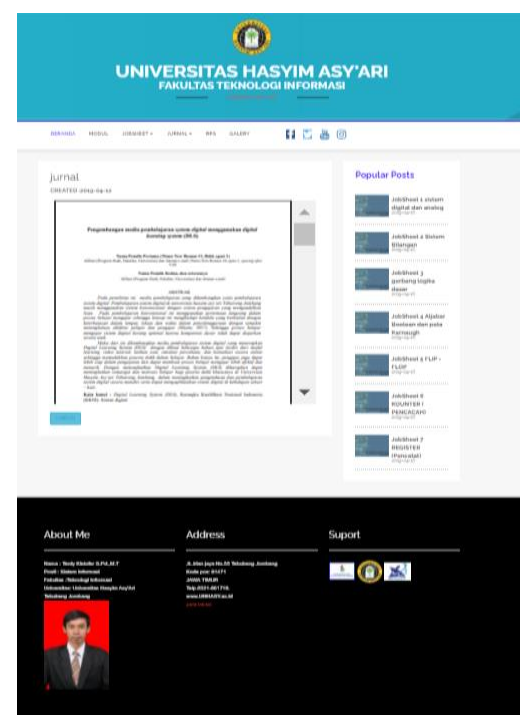

(d)

Gambar 9. Website Media Pembelajaran Sistem Digital

\section{Keterangan}

(a) Modul Sistem Digital dapat Diunduh;

(b) Jobsheet dan video tutorial sesuai materi;

(c) Tampilan Jurnal dapat diunduh; 
(d) Tampilan RPS;

2. Data Respon Mahasiswa.

Data respon mahasiswa yang terdiri dari pendapat dan juga saran diambil pada mata kuliah sistem digital berbasis website yang dikembangkan dengan model Digital Learning System (DLS) yang mengacu pada standart standard Kerangka Kualifikasi Nasional Indonesia (KKNI) menggunakan lembar angket respon mahasiswa. Hasil dari penelitian ini berupa data lengkap respon mahasiswa Teknik informatika FTI UNHASY pada tabel 2

Tabel 2. Hasil Angket Respon Mahasiswa

\begin{tabular}{|c|c|c|c|c|c|c|c|c|c|c|c|}
\hline \multirow{2}{*}{ No } & \multirow{2}{*}{ Nama Mahasiswa } & \multicolumn{10}{|c|}{ Angket Respon } \\
\hline & & 1 & 2 & 3 & 4 & 5 & 6 & 7 & 8 & 9 & 10 \\
\hline 1 & Mahasiswa 1 & 3 & 3 & 3 & 3 & 3 & 3 & 3 & 4 & 2 & 2 \\
\hline 2 & Mahasiswa 2 & 4 & 3 & 3 & 3 & 5 & 3 & 3 & 3 & 2 & 2 \\
\hline 3 & Mahasiswa 3 & 3 & 4 & 4 & 3 & 3 & 3 & 3 & 4 & 2 & 2 \\
\hline 4 & Mahasiswa 4 & 3 & 3 & 3 & 3 & 3 & 3 & 3 & 4 & 2 & 2 \\
\hline 5 & Mahasiswa 5 & 4 & 3 & 3 & 4 & 5 & 3 & 3 & 3 & 2 & 2 \\
\hline 6 & Mahasiswa 6 & 4 & 3 & 4 & 3 & 2 & 3 & 3 & 3 & 4 & 3 \\
\hline 7 & Mahasiswa 7 & 4 & 3 & 3 & 3 & 3 & 3 & 3 & 3 & 4 & 3 \\
\hline 8 & Mahasiswa 8 & 3 & 3 & 4 & 3 & 3 & 3 & 3 & 4 & 2 & 2 \\
\hline 9 & Mahasiswa 9 & 3 & 3 & 4 & 3 & 3 & 3 & 3 & 3 & 2 & 2 \\
\hline 10 & Mahasiswa 10 & 3 & 3 & 4 & 3 & 3 & 3 & 3 & 4 & 3 & 2 \\
\hline \multicolumn{2}{|c|}{ Rata-rata respon Mahasiswa } & 3.4 & 3.1 & 3.5 & 3.1 & 3.3 & 3 & 3 & 3.5 & 2.5 & 2.2 \\
\hline \multicolumn{2}{|c|}{$\begin{array}{l}\text { Rata-rata respon Mahasiswa } \\
\text { keseluruhan }\end{array}$} & \multicolumn{10}{|c|}{3,06} \\
\hline
\end{tabular}

Pengamatan dilakukan dalam pembelajaran dengan menuliskan aktivitas mahasiswa oleh dosen mata kuliah sistem digital. Hasil pengamatan kegiatan pembelajaran sistem digital terdapat pada tabel 3

Tabel 3. Hasil Pengamatan Kegiatan KBM

\begin{tabular}{llccc}
\hline \multirow{2}{*}{ No } & \multicolumn{2}{c}{ Kategori Pengamatan } & \multicolumn{3}{c}{ Presentasi Pengamatan Belajar } \\
& & Mahasiswa (\%) & \\
\cline { 3 - 5 } & & Pertemuan 1 & Pertemuan 2 & Rata-rata \\
\hline 1. & Memperhatikan dosen yang & $30 \%$ & $21 \%$ & $39 \%$ \\
2. & Menjelaskan & $19 \%$ & $11 \%$ & $21 \%$ \\
3. & Bekerja dengan website sistem digital & $21 \%$ & $28 \%$ & $16 \%$ \\
4. & Menulis yang relevan dengan KBM. & $11 \%$ & $20 \%$ & $4 \%$ \\
5. & Berdiskusi atau tanya jawab. & $15 \%$ & $15 \%$ & $14 \%$ \\
6. & Perilaku yang tidak relevan dengan & $6 \%$ & $5 \%$ & $6 \%$ \\
\hline & KBM. & $100 \%$ & $100 \%$ & $100 \%$ \\
\hline
\end{tabular}

Dari tabel pengamatan diatas memperhatikan dosen dalam menjelaskan dengan presentasi rata - rata sebesar 39\% berdasarkan analisa bahwa mahasiswa dapat mengerjakan latihan soal dengan baik pada tiap bab mata kuliah sistem digital dan ketika terdapat mahasiswa yang belum paham tentang materi pembelajarannya mahasiswa dapat langsung belajar melalui website sistem digital yang dapat diakses dimana saja dan kapan saja.

3. Grafik Hasil Respon Mahasiswa. 


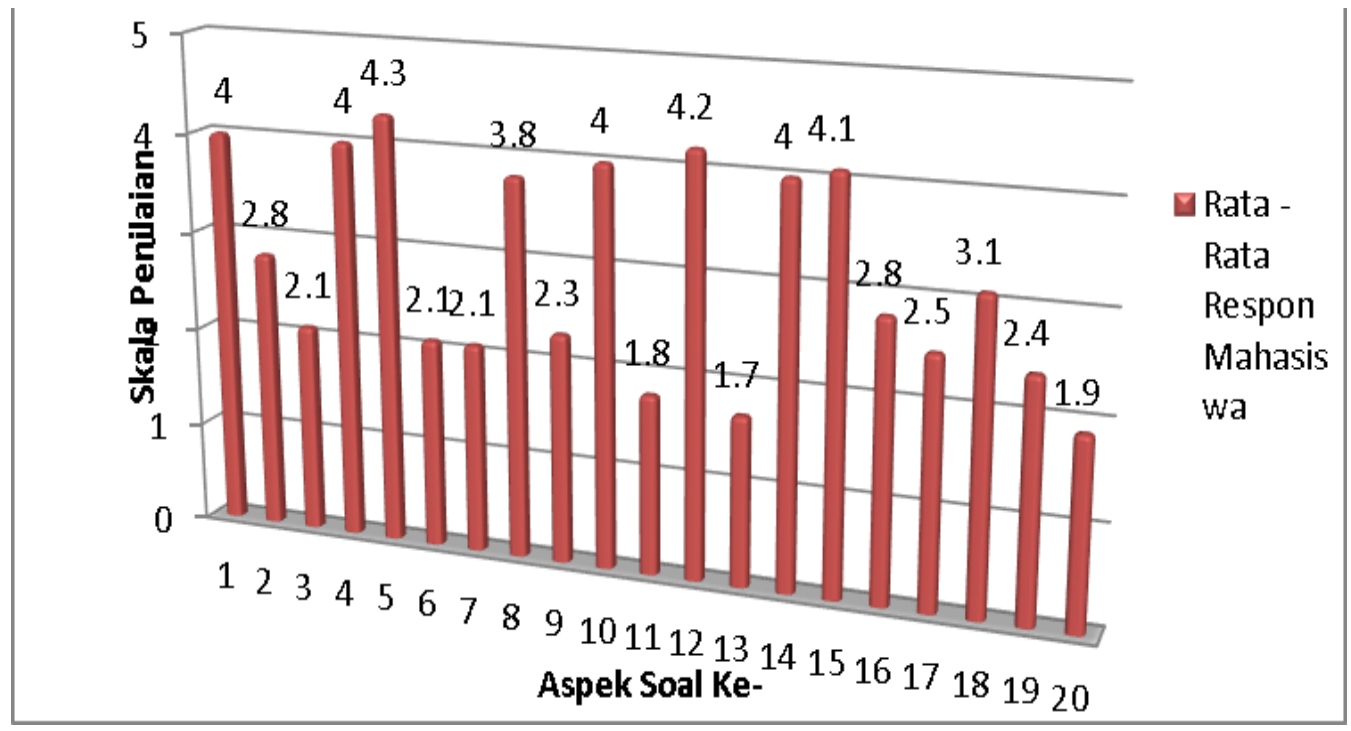

Gambar 10. Hasil Respon Mahasiswa.

Dari hasil angket respon mahasiswa pada gambar 10 pada media pembelajaran sistem digital menggunakan Digital Learning System (DLS) dengan media website mendapatkan hasil ratarata 3,06 dengan rating 81,2\% (kategori baik). Mahasiswa Prodi teknik Informatika sangat bersemangat dan merespon dengan positif pada media pembelajaran yang di buat berstandar kompetensi KKNI mempelajari sistem digital menggunakan Digital Learning Sistem (DLS) dengan salah satu bukti dari data yang didapat pada angket untuk respon dan komentar mahasiswa tertulis "Dengan Belajar menggunakan DLS dapat meningkatkan dan mempermudah dalam pembelajaran", respon dan komentar kedua "Belajar sistem Digital menggunakan DLS berbasis website menjadi lebih menarik dan tidak monoton" dari kedua statment itu sehingga dalam belajar sistem digital dapat ditingkatkan dan lebih mudah jika media pembelajaran yang digunakan dalam belajar tidak monoton dan lebih menarik.

\section{KESIMPULAN}

Pengembangan media pembelajaran sistem digital menggunakan Digital Learning System (DLS) dengan menggunakan media website terdapat berbagai menu selain dari beranda. Selain itu juga terdapat menu jobsheet dan video tutorial, E- modul, RPS, jurnal dan galeri. Dengan dikembangkannya website pembelajaran mata kuliah sistem digital dapat membantu dosen dalam menyampaikan materi perkuliahan pada mahasiswa Prodi Informatika FTI UNHASY. Mahasiswa juga dapat meningkatkan pemahaman, motivasi dan semangat belajar sistem digital secara personal dan mandiri.

\section{UCAPAN TERIMA KASIH}

Peneliti Mengucapkan syukur kehadirat Allah SWT serta orang tua yang selalu mendoakan dan memberi arahan sehingga jurnal ini dapat selesai dan tersusun dengan baik dan Terima kasih Kepada Universitas Hasyim Asy'ari Tebuireng Jombang sudah memfasilitasi serta kepada Direktorat Riset, Teknologi, dan Pendidikan Tinggi (RISTEK DIKTI) atas dukungan yang diberikan peneliti berupa dana bantuan penelitian yang menunjang keberlangsungnya penelitian ini sehingga berjalan dengan baik.

\section{DAFTAR PUSTAKA}

[1] T. Triwiyanto, Pengantar Pendidikan. Jakarta: PT. Bumi Aksara, 2014.

[2] S. R. Muntu, "Pengembangan Media Pembelajaran Berbasis Web Pada Mata Pelajaran Simulasi Digital Kelas X di SMK,” Universitas Negeri Makasar, 2017.

[3] H. Molenda, Instructional media and technology for learning. London: Pearson, 2014. 
Digital Learning System (DLS) Sebagai Model Pengembangan Media Pembelajaran Mata Kuliah Sistem Digital Berbasis Website Di Jurusan Teknik Informatika Universitas Hasyim Asy'ari Tebuireng Jombang

Terdy Kistofer, Ginanjar Setyo Permadi, Tanhella Zein Vitadiar

[4] T. Kistofer, G. S. Permadi, and T. Z. Vitadiar, "Development of Digital System Learning Media Using Digital Learning System," in 1st Vocational Education International Conference (VEIC 2019), 2019, pp. 177-182.

[5] E. Y. Pramesti, "Penggunaan Digital Learning System (Dls) Sebagai Pembelajaran Berbasis Teknologi Di Smp Negeri 5 Surabaya," Universitas Airlangga Surabaya, 2018.

[6] E. Prihatin, Guru Sebagai Fasilitator. Bandung: Karsa Mandiri Persada, 2008.

[7] R. Kamatchi, "Software Engineering: Web Development Life Cycle," Int. J. Eng. Res. Technol., vol. 2, no. 3, pp. 2278-0181, 2013. 